\title{
Reducing Inequality: Taking from the top to distribute at the bottom
}

\section{Agatha Kratz}

Translator. Peter Brown

\section{OpenEdition \\ Journals}

\section{Electronic version}

URL: http://journals.openedition.org/chinaperspectives/6285

DOI: 10.4000/chinaperspectives.6285

ISSN: 1996-4617

\section{Publisher}

Centre d'étude français sur la Chine contemporaine

\section{Printed version}

Date of publication: 1 September 2013

Number of pages: 80-82

ISSN: 2070-3449

\section{Electronic reference}

Agatha Kratz, « Reducing Inequality: Taking from the top to distribute at the bottom », China

Perspectives [Online], 2013/3 | 2013, Online since 01 September 2013, connection on 15 September 2020. URL : http://journals.openedition.org/chinaperspectives/6285

(c) All rights reserved 
This section, prepared by Asia Centre (www.centreasia.eu) is mainly based on the Chinese-language press and aims at explaining the debates ongoing in the PRC, at Hong Kong or in Taiwan on international questions and issues related to Greater China.

\section{China Analysis Les Nouvelles de Chine}

\section{Reducing Inequality: Taking from the top to distribute at the bottom}

\section{Analysis by Agatha Kratz based on the following sources:}

- Gan Li, (1) “缩减收入差距” (Reducing income disparity), Caijing, 6 January 2013.

- Zhu Guozhong, (2) "“二次分配'难奏效" (The 'second distribution' struggles to deliver), Caijing, 6 January 2013.

- Chen Tao, (3) "什么在影响中国人未来的收入" (What will influence the future incomes of the Chinese?), Nanfang zhoumo, 3 January 2013.

- Feng Lei and Qiu Yue, (4) "收入分配改革警惕四大误区" (The four mistakes of the reform in income distribution), Guangming ribao, 28 January 2013.

- Editorial, "跳出分配看收入分配改革" (Getting away from the concept of redistribution to look at the reform of redistribution), Diyi caijing ribao, 19 December 2012.

n the words of Chen Tao, 2012 was a watershed year during which the political and public spotlight turned from concerns about GDP and growth to focus more on the redistribution of wealth. Articles by Chinese researchers, journalists, and academics have also broadly addressed the twin subjects of sustainable growth and quality of development. The question of fair income distribution holds an important place in all of them. Discussion of this matter has been given a new lease of life by the publication of the first official Gini index since 2008, which, according to the National Bureau of Statistics (NBS), dropped from 0.49 in 2008 to 0.47 in 2012, and through the launch of a "reform plan for income distribution" (shouru fenpei gaige fang'an 收入分配改革方案), put before the National People's Congress in March.

The writers recognise the extent of efforts carried out by the government, and note the importance, symbolically at least, of the measures announced in the redistribution plan. They all confirm that it was high time for the government to tackle the issue of inequality, as strong growth without equitable redistribution will be increasingly difficult to justify in the future, and potentially fraught with social risks.

However, a number of criticisms have quickly appeared: Beijing's figures are said to be unrealistic, as is the proposed programme itself. What is the reality of social, economic, and territorial inequality in China? What does the action plan provide for, and if it is inadequate, what are its weaknesses?

\section{The scope and details of income disparity in China}

There is little data available for measuring income disparity in China, and even when it does exist it is not always consistent. In this context, the Gini coefficient (ji'nixishu 基尼系数) is doubtless the "least bad" tool for comprehending these inequalities. According to the latest official figures (from the NBS), in China, the Gini coefficient stood at $0.4744^{(5)}$ in 2012. Despite being high - the world average is 0.44 - this result is contradicted by several sources. Indeed, in 2010, the UN published its own calculation of the Chinese index and obtained a ratio of around 0.52 .

That same year, the Survey and Research Centre for Household Finance in Southwest China, headed by Gan Li, also published a study on the subject, the Chinese Households Financial Survey (CHFS). According to this report, the country's Gini coefficient was probably closer to 0.61 . This body broke the ratio down into 0.56 for urban households and 0.60 for rural households. It also appears from this study that the main source of income inequality in China is disparity in salaries. In urban areas, $53 \%$ of income inequality comes from differences in salary; in the countryside the Gini index is made up of $33 \%$ for the industrial sector and $22 \%$ for agriculture. The CHFS also shows that the more a region is developed and its economy liberalised, the more marked the gaps are. The study showed the 2010 Gini coefficient to be 0.59 in the east of the country, 0.57 in the centre, and 0.55 in the west. Gan Li is very sceptical about whether disparities decreased in China between 2010 and 2012, and hence about the proportions referred to in these two studies. Gan Li speculates that these divergences stem in particular from the fact that over the past ten years, the NBS figures have only taken rural households into account.

In spite of divergences in the conclusions drawn by the three sources, they all put China above the international average, and show the real nature of the problem of income distribution in the country. The figures put forward by Gan Li even place China among the most unequal countries in the world. In his view, whilst it is normal for a country going through a rapid growth phase to have a high Gini index, a value of 0.61 is exceptionally high.

\footnotetext{
. Director of the Survey and Research Centre for Household Finance in Southwest China.

Professor at the Guanghua School of Management, Peking University.

Economics journalist, Nanfang zhoumo.

Feng Lei and Qiu Yue are both journalists for Guangming ribao.

Figures provided by the National Bureau of Statistics (NBS), cited by Feng Lei and Qiu Yue.
} 


\section{The introduction of government measures}

The Chinese government, aware of the risk of social, economic, and political tensions associated with such income disparity, launched discussion in 2012 as to how to rebalance the spatial and social distribution of income in China. The upshot of this initiative took the form of an action plan for reform of distribution, which was put before the National People's Congress in March.

Zhu Guozhong observes that this reform had already been under discussion (in other forms) for the better part of eight years. The extent of the problem, its controversial nature, the strong resistance in some circles, and the many delays and postponements in the debate account for the exceptionally long process. During the same period, however, public interest continued to grow to the point that a large portion of the population is now palpably impatient for concrete measures.

Even before its publication, ${ }^{(6)}$ the action plan had already been subject to numerous criticisms, especially by the writers referred to here. One encouraging point, however, as Zhu Guozhong concedes, is the fact that the government has finally resolved to "take from the rich to give to the poor" (jiefujipin 劫富济贫). In order to carry this out, the plan provides for fiscal reform (and in particular an increase in taxation of the well-off), and a growth in financial transfers to low-income sections of the population. That will not be enough, however, to solve the many problems related to income inequality in China.

\section{The inadequacies of the redistribution law}

Firstly, the economic authorities have not made clear what the principal source of the new fiscal revenue would be. Even if, in theory, these contributions should come from the high-income bracket, Zhu Guozhong is concerned by the fact that these are often the very people with power, connections, and influence and that they could use these levers to avoid paying the new levies. This would mean that the burden of the reform would fall on the middle classes, who earn enough to be taxed more but who do not have enough influence to avoid new taxes. Zhu Guozhong explains that the government runs the risk of "fleecing the middle class" zhongchanjieji bei jian yangmao 中产阶级被剪了羊毛) or "milking the middle classes to save the poor" (sougua zhongceng jieji diceng 搜刮中层接济底层). The writer adds that while the middle class will gradually become "lean and weak" (shouruo 瘦弱), the "cake" (dangao 蛋糕) of the rich will continue to get bigger. This measure will therefore not settle the problem of inequality, since it will be felt especially by the middle classes whilst largely sparing high-income earners.

Furthermore, the tax hike will have at least two perverse effects. The one will be to reduce investment by tying up important resources, and the other will be to reduce the purchasing power of the middle classes, which flies in the face of the government's objective of promoting domestic consumption.

Finally, Zhu Guozhong's main regret concerns the little importance that this reform gives to the concept of economic opportunity, at least as he sees it. He paints a picture of Chinese society as a pyramid, at the top of which are the well-to-do, relying on their networks and their influence, enjoying privileges and the majority of economic opportunities. The middle classes have to rely on their abilities and qualifications, sometimes managing to seize the odd opportunity that comes their way. The less well-off por- tion of the population has no access to economic opportunities and is trapped in poverty. Zhu goes on to say that state monopolies and corruption only serve to exacerbate these inequalities of opportunity.

\section{Solutions and improvements proposed by the writers}

The writers propose a certain number of adjustments to the government action plan.

Feng Lei and Qiu Yue refer to Zheng Bingwen, the Director for the Centre for International Social Security in the Academy of Social Sciences, who believes that it should be left to the market place to ensure the optimal allocation of resources. If market mechanisms were more efficient in China, with fewer distortions, economic opportunities would increase and bring about an increase in income for the poorest portion of the population.

The Diyi caijing ribao editorial reminds us that remedying income disparity in China is a long-haul task. Even if direct redistribution is an effective shortterm solution in that it gives some comfort to families in need, it will take more than a fiscal reform to settle the problem of disparity between the cities and the rural areas. To achieve this, the state will have to use development as its main tool, and in particular will have to strive relentlessly for economic catch-up by giving greater access to those who have lacked it. By relying on the "cake" of the richest regions, the government will be able to put in place a series of measures promoting economic activity in the disadvantaged regions.

Gan Li proposes that direct redistribution and an increase in the basic wage should not be the focus, as these introduce distortions and affect lowincome earners by limiting the hiring of new labour. In his view, methods of secondary redistribution such as improving public services, widening the social security net, and increasing "transfers" (zhuanyizhifu 转移支付) and social benefits are more effective levers. Liberalising public enterprises and monopolies, etc., should also be encouraged. Lastly, over the long term, investment in education will play a major role in promoting equality of opportunity and ensuring less inequality in levels of income.

Gan Li insists on the need to develop China's social security system. He takes the view that a "perfect social insurance system" (wanshan shebao xitong 完善社保体系) can markedly reduce the perverse effects of income inequality. This system is still very under-developed in today's China, where the 2011 social security outlay represented only $12.3 \%$ of public expenditure (taking into account China's Social Insurance Fund), as against $36.6 \%$ in the United States. Gan Li informs us that public assistance to households in need is also inadequate. In $2010,71 \%$ of households living below the standard poverty line of $\$ 1.25$ a day received no help from the government. Support is also lacking for the aged. According to the same CHFS report, in $2010,45 \%$ of retirees received no pension or other help from the state. Furthermore, only $30 \%$ of retrenched workers had a right to unemployment benefits. Lastly, although China's health insurance scheme is very broad, covering a large part of the population, it remains too weak and uneven, with major discrepancies in access to the particular disadvantage of the rural population. Harmonising cover between urban and rural areas would already enable a reduction in post-redistribution income disparity.

6. The articles quoted here were published before the publication of the Plan, and even before it was presented to the National People's Congress. 


\section{The Chinese government has the financial means to carry out these reforms, but does it have the courage to implement them?}

Simple solutions for reducing inequalities in China do therefore exist. All they require, according to $G$ an $L$ i, is a small increase in public expenditure and taxation.

China today has the financial resources to implement effective measures to reduce income inequality. The writer states that the 2011 gross public income was in the vicinity of 10,000 billion yuan, 2,000 billion of which could easily be released to finance these reforms. This windfall corresponds roughly to the profit level of public enterprises, which pay only $2 \%$ of their revenue to the state.

According to Gan Li, a "reasonable" policy would already have spectacular results. By redistributing - directly or indirectly - to $60 \%$ of the poorest families, the government could bring the Gini coefficient down from 0.6 to 0.4 according to the CHFS's figures.

However, as the editorial in the Diyi caijing ribao reminds us, this reform will be difficult to implement, as it requires "lifting the bottom (tidi 提低), broadening the middle (kuozhong 扩中), and putting a cap on the top (konggao 控高)" of the social pyramid. In order to reduce inequality in China, what will be required therefore is a complete overhaul of the country's economic structure by questioning the privileges of the well-to-do and sharing their "cake" with the middle classes and the disadvantaged.

This same editorial stresses that reducing disparity would need a change of "system" (xitong 系统), implying that income reform is one component in the general reform of China's economic system. If implemented, this reform will challenge a number of vested interests. In the past, such reforms were often embarked upon and then encountered resistance from interest groups. Often too, such plans "ended up being left by the wayside" (zuihou zhihao buliaoliaozhi 最后只好不了了之). In the view of these editorial writers, the government will therefore have to show not only "courage and political wisdom" (zhengzhi yongqi he zhihui 政治勇气和智慧), but above all “determination” (juexin 决心).

\section{No Administrative Solution in Sight for Urban "Air-pocalypse"}

\section{Analysis by Giulia C. Romano based on the following sources:}

-Yi Peng, (1) "雾雷对城镇化的影响” (The influence of haze on urban development), Caixin, 19 February 2013.

- He Chunlu, (2) "'毒空气'凸显中国式低碳治理困境" ('Poisoned air' underlines the difficulties in the Chinese approach to low carbon management), Zhongguo kexue bao, 16 January 2013.

\section{Urbanisation and pollution}

"H aze" has recently become one of the most popular words in China. What immediately springs to mind is the exceptionally high levels of pollution recorded in Beijing, which, at the height of the phenomenon (at the time of the articles cited), was an unprecedented 886 micrograms per cubic meter, (3) according to the US Embassy's observation stations for air quality.

Yi Peng sees several causes for the recent blanket haze over the Beijing-Tianjin-Hebei region. First, in the worst days of this "air-pocalypse" (kongqi mori 空气末日, to quote the expression used by the press), an absence of cold air currents and wind was a very important factor. The lack of natural ventilation caused a strong concentration of pollutants in the atmosphere, at a relatively stable level, and did not allow for their dispersal. He also points to other factors, particularly pollution from motor vehicles, industrial output, and high-density population, as well as the energy needs of buildings. These ancillary factors, which are also of major importance, are all more or less connected to urbanisation. This leads our writers to rethink China's current urban planning models. For Yi Peng, Beijing has to become the symbol of a new way of thinking about urban development.

\section{What solutions?}

The Chinese capital has, according to Yi Peng, the highest level of public services in the country. Due to this abundance of administrative resources, the city is host to a population approaching 20 million and, according to the writer, could one day be home to nearly 50 million residents. Although Beijing is probably in a position to accommodate a population of that size in terms of services, financial means, or on account of its size, the appearance of intense haze over the past few months is an important signal that raises the question of whether Beijing can really sustain such a level of urbanisation and whether the city can really continue to grow.

These questions concern all major Chinese cities and make us wonder about their potential for future growth and whether they will be capable of resisting the enormous environmental pressures related to urbanisation.

In the words of Yi Peng, in order to avoid having mega-cities like Shanghai or Beijing "hit the wall" (qu chu bi 去触壁), a planned approach will be re-

1. Researcher in the Research Centre on Human Resources at the Peking University and editorialist for several economic newspapers, such as the Chinese version of the Financial Times, Zhongguo jingying bao, Jingji guancha bao, etc.

2. Journalist for Zhongguo kexue bao.

3. Average hourly concentration is PM 2.5 in the atmosphere. 